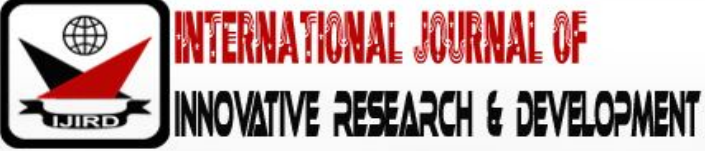

ISSN 2278 - 0211 (Online)

\section{Perceptions of Undergraduate Students on the University Teaching Practice Assessment Process in Kilimanjaro Region, Tanzania}

\author{
Dr. Malusu J, M. \\ Seneiour Lecturer, Department of Education, Mwnge Catholic University, Tanzania \\ Dr. Gadi M. Koda \\ Lecturer, Department of Education, Mwnge Catholic University, Tanzania \\ Mariapia Kayombo \\ Masters Student, Department of Education, Mwnge Catholic University, Tanzania
}

\begin{abstract}
:
The Tanzanian government, through its Ministry of Education Science and Technology has done a lot to improve teaching practice for student teachers. However, the situation has not improved much in various universities in Kilimanjaro Region. The study aimed to investigate the perceptions of undergraduate students towards University Teaching Practice Assessment process in Kilimanjaro region, Tanzania. The study was guided by six (6) research questions. Two hypotheses were tested. The study employed mixed methods approach under which a Convergent Parallel design was used. Both probability and nonprobability sampling procedures were used to sample the target groups. Simple random, purposive and stratified sampling techniques were used to determine the study sample that consisted of 185 respondents including 20 lecturers, 162 students and 3 teaching practice coordinators. Lecturers and TP coordinators were drawn by the use of purposive sampling while students were stratified into groups and then randomly picked from each stratum. Instruments used for data collection included: questionnaires and interview guide. Validity of the instruments was determined through experts and reliability coefficients of scales from undergraduate students' questionnaires were computed and found to be 0.633. Quantitative data were analyzed in terms of percentages, frequencies, and mean scores by using Cronbach Alpha with the aid of Statistical Package for Social Sciences (SPSS). Qualitative data was analyzed through narration and direct quotation. Findings revealed that, undergraduate students perceive teaching practice assessment process positively since it helps them to become competent teachers of the future. One-way ANOVA and independent t-test were used to test hypotheses.
\end{abstract}

Keywords: Assessment, teaching practice assessment, perception of undergraduate students

\section{Introduction}

Educational assessment gained momentum after the Second World War, where tests were used to determine academic achievement and attainment (Aiken, 2000). In college of education, however, oral examinations were firstly introduced in Europe in 1219 followed by written tests which were firstly used by the Jesuits in the 1500s (Sax \& Newton, 1997). Today, educational assessment is done together with teaching and trainings which have added credits in the award. Teaching Practice is the central activity in developing teaching skills gathered in classroom learning and in preparing professional teachers in any country (Thungu, 2010). In all professional fields, training is a crucial aspect with an attempt of testing and assessing the skills attained by learners before the actual implementation in the world of work. This fact stands as vital to the teaching profession where teacher-trainees need to attend field training for the purpose of assessing their teaching skills and testing the theories learned in classrooms in actual school context, before graduating as professionals.

The undergraduate student is obliged to attend field training of almost 4 to 10 weeks in which the application of the theoretical knowledge learned in colleges or universities is put into practice. Teaching practice for teachers is done to develop the quality of good education as teaching professional depends on how well teachers have been prepared in teaching methodologies, appropriate knowledge, skills, attitudes and behavior (Lukanga, 2013). Teachers have great role in preparing competent student-teachers towards good and quality education. They are required to have abilities in organization of materials, assertive discipline, classroom management, integration of all aspects of teaching, stating clear objectives, focusing on objectives and improvise methods, encouraging students to exceed, stating of competency goals and possessing authority to implement the curriculum.

The importance of teaching practice is identified by various scholars as: the most important stage in preparing competent teachers; gain the experiences in a real school and classroom situation. It prepares the learners' mind to receive 
constructive criticism, discovering teaching strengths and weakness and developing a core set of pedagogic values to which a professionally competent teacher adheres to (Alsaid, (2001); MoEVT, (2011); Donald \& Hoffman, (2011); Bhargara \& Pathy, (2011); \& Demuth, (2013). Issues concerning preparing scheme of work, lesson planning, visualizing, class control, critical thinking, decision making and problem solving are expected to strengthen a student teacher (MOEVT, 2011). Further, it offers the context for student teachers to develop their personal teaching competence (Smith \& Lev-Ari, 2005) and to develop important professional knowledge such as knowledge of people, knowledge of themselves, selfcontrol and inter-personal sensitivity -all of which are important traits that would see them through their professional lives.

During teaching practice assessment, students' perceptions are held as an important ingredient for improving teachers' professionalism, it enables lecturers and trainees do better in the program. Perceptions for this case are the beliefs held by undergraduates on the teaching practice assessment program, which can be perceived positively or negatively (Bogman \& Biklen, 1992). During teaching practice, the student teachers interact with environment, society surrounding, experienced teachers, all these create different perceptions of students towards teaching practice (Cherry, 2013). Bakhshi, Hassanshahi and Bakhialiabad (2015) argue that meaningful learning correlates positively with the students' perceptions of the educational environment, which impacts on students' learning, experiences and outcomes.

Popham, (2008); Mussawy (2009) argue that, teaching practice assessment process which is practiced fairly enhances learning, provides feedback about student progress, builds self-confidence and self-esteem, grading of student work, design, clear directions, and develops skills in evaluation. With a fair teaching practice assessment process, educators can then analyze their teaching practice assessment processes and draw on the extent students, as learners, involving students in decision making about assessment tasks. In response to this view, students' perception is strongly achieved by fairness in assessment, and, henceforth, acts as a conducive atmosphere for achievement of objectives.

On the other hand, Alnaji, (2000); Jahin\& Alexander (2006); and Al-magableh, (2010), argued that in various countries the assessment of undergraduate students during their Teaching Practice program is not stable, and it has brought about variation in perceptions of undergraduate students towards it. The scholars have not given the reasons why the program is not stable. Are the problems caused by lecturers? Are they able to overcome the problems? Chireshe, \& Chireshe, (2010) argued that in South Africa the problems relating to the supervisor and cooperative teachers included: abandoning student teachers during teaching practice, not checking their lesson plan books and being overwhelmed with other activities while students' teachers are engaged in teaching.

However, in Tanzania Mahende \& Mabula, (2013) argued that the same problems relating to the supervisor and cooperative teachers have made the perceptions of students unclear and therefore fail to effectively prepare undergraduate students to become competent professionals. According to Jahin, (2006); Matto \& Madila, (2014) and Bachore, (2016) the practice requires strengthening the teaching practice supervision exercise and specifically the collaboration between university teaching practice office and the teaching practice-host institutions, the time coverage of the assessment process and numbers of mentors are both insufficient, it is said that university lecturers when assessing trainees tend to move from one institution to another hence fail to carry out their assessment duties effectively.

In spite of concern of many of the researchers most of them have not addressed the perceptions held by undergraduate students towards Teaching Practice Assessment process involving lecturers during assessment. This therefore, prompted the current study to be carried out with the focus of investigating the perceptions of undergraduate students towards teaching practice assessment process in Kilimanjaro region.

\section{Statement of the Problem}

The undergraduate students' perceptions towards teaching practice assessment programmes are vital aspects in determining their progress in their studies. However, the program faces many challenges in various training universities. Much effort has been put by the government of Tanzania for a good and reliable assessment, for instance, according to TCU (2014), the government through its Ministry of Education has set guidelines of assessments in which mentors ought to rely on, like fairness in assessments, equitable in assessments, and provision of feedback on time when assessing undergraduate students.

Despite various criteria that have been put by the government to improve teaching practice assessment, the challenges in teaching practice assessment still exist in universities in Kilimanjaro region. The criteria for assessment are not well stated as some students experience difficulties in understanding them. Most of students-teachers even after being assessed by lecturers, they do not prepare well the teaching and learning materials (Ngussa \& Kuboja, 2015). Malik and Ajmal (2010) stated that student- teachers perceive teaching practice as a stressful period which involves a heavy workload when being observed, assessed by teachers, during the use of teaching methods and classroom management. They identified supervision workload other than teaching, and content knowledge as challenges many student teachers face during teaching practice (Goh\& Matthews, 2011).

Although, the Ministry of Education has provided guidelines on conducting assessments on teaching practice to meet objectives, still the assessment is a problem which has forced the researchers' mind to think that there was a need to conduct a study to find out how do the undergraduate students perceive teaching practice assessment, and how does it help them to become competent teachers.Therefore this study investigated the perceptions of undergraduate students on the university teaching practice assessment process in Kilimanjaro region, Tanzania.

\section{Research Questions}

This study was guided by the three research questions framed to obtain data to respond to the quest of the study. These are: 
- What are the perceptions of undergraduate students towards feedback provided by lecturers after teaching practice assessment?

- What are the challenges encountered by undergraduate students during teaching practice in Kilimanjaro region?

- How can teaching practice supervision of undergraduate students be improved in Kilimanjaro region?

\subsection{Null Hypotheses}

- Hypothesis1: There is no significant difference in the mean perceptions of undergraduate students in teaching practice when compared by gender.

- Hypothesis2: There is no significant difference in the mean perceptions of undergraduate students in teaching practice when compared by age.

\section{Conceptual Framework}

Conceptual framework refers to the tool in research that aims at enabling the researcher develop awareness and understanding of the situation under scrutiny and to communicate it to reader (Kombo\& Tromp, 2006). The conceptual framework of this study is illustrated in the following diagram.

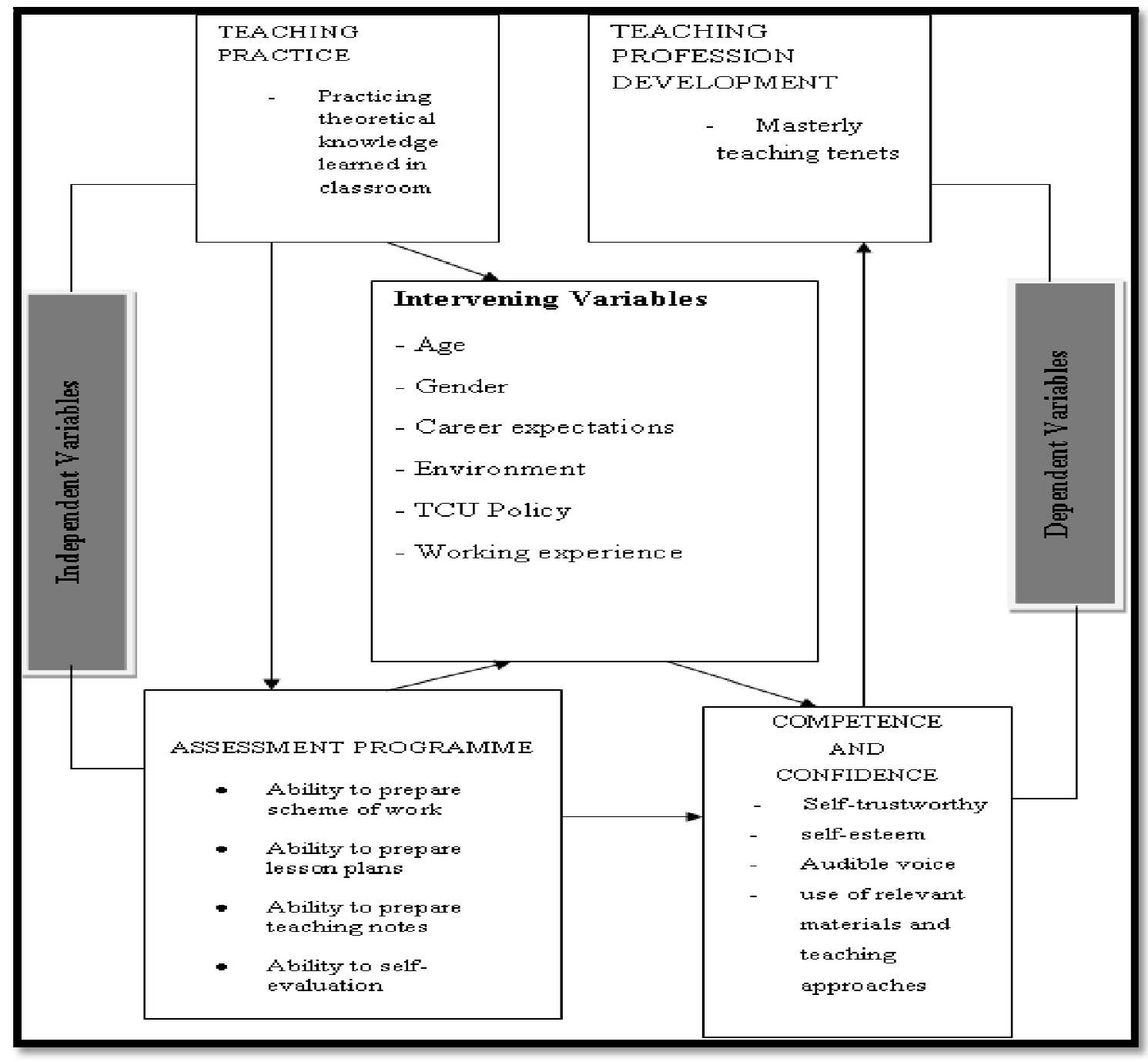

Figure 1: Conceptual Framework

In Figure 1, the inter-relationship between independent variables and dependent variables is illustrated. Teaching practice and assessment program are independent variables which when done precisely results to a win-win relation with the outcomes. Teaching practice is one of the teacher training programs in which trainees engage in the practicability of the learned theoretical knowledge. It is focused much with the presentation of body of knowledge and the precise use of methods and approaches. When done properly, is likely to result to the appealing score from assessment and therefore lead to the better results.

Assessment program measures how a student is enriched with the teaching tenets. The assessor peers into practicing fields to observe how practically teaching is fulfilled, checking portfolios (scheme of works, lesson plans, lesson notes and assessment tools). The precise achievement of a student in assessment is largely predetermined by how well was taught in classroom and the positive perceptions towards the assessment. The effective practicability of this, leads to favorable dependent variables. 
Dependent variables: Competence and confidence play dependent variables resulting to the precise independent variables. Competence and confidence are achieved from equitable and fair assessment together with teaching practice. The mastering of the teacher training programs due to student-teachers' perceptions expected to add to their competence in subject matter and teaching methodologies. A well taught student is likely to become competent whereas confidence is achieved. These two make a student interact with all the learning programs and henceforth develops in teaching profession becoming a professional teacher. On the other hand, there are a set of factors known as intervening variables which alter the interaction between the independent and dependent variables such as: age, gender, carrier expectations, environment, TCU policy and working experience of the undergraduate students which are assumed in this study, but can directly or indirectly influence the interaction between dependent and independent variables.

\section{Literature Review} following:

Different literatures were reviewed to aid the discovery of reliable findings. These studies involved were the

\subsection{The Perceptions of Undergraduate Students towards Feedback Provided by Lecturers after Teaching Practice Assessment}

Planella (2013) investigated about "Students' perception of peer assessment" University of Girona. Questionnaires were administered before and after the peer assessment process to 416 students studying 11 different subjects in four different fields taught at the University of Girona. Results suggest that students have a positive predisposition towards this methodology, both before and after its implementation. Students perceive it as both motivating and recommended methodology that facilitates the acquisition of learning at different levels. As for its limitations, students highlight the responsibility that comes with it and a certain amount of distrust in fellow students' abilities to peer-assess.

The study about, "Perception of Students towards Participation in Teaching Practice Exercise in Ekiti State University" was conducted by Olugbenga in 2013. It was an empirical research based on descriptive research design. The sample for the study consisted of 1200 students in the Faculty of Education of the university, who were selected using stratified and simple random sampling techniques. Data collection was accomplished with the use of a questionnaire which was used to gather information for the study. Two research questions were generated while three hypotheses were formulated. The research questions were answered using descriptive statistics of means and percentages while the hypotheses were tested through an inferential statistic of t-test at 0.05 significance level.

The findings of the study revealed that most of the students are not favorably disposed to teaching practice exercise. However, 400 level students fare better in terms of positive perception about teaching practice exercise. Recommendations were proffered on ways to adequately induct the students on the relevance of teaching practice exercise to their training. The perception of the students about this important exercise in their training was therefore found to be not impressive. The study focused on the perceptions of Students towards Participation in Teaching Practice Exercise, and not the perceptions of undergraduates towards teaching practice assessment process as the current study.

Cheng (2015) conducted a study to explore "The relationship between students' perceptions of assessment tasks and classroom assessment environment, within the university context of teaching English as a foreign language (EFL) in China". A questionnaire was designed and administered in order to measure students' perceptions of the classroom assessment environment. PATI includes five subscales: congruence with planned learning, authenticity, student consultation, transparency, and diversity. Alkharusi's scale comprises two subscales: learning-oriented classroom assessment environment and performance-oriented classroom assessment environment. Participants were 620 university students from three universities in China.

The factor analysis findings identified the original five-factor PATI, and Alkharusi's two-factor scales within this Chinese research context. Multiple regression analyses exploring the interrelationship showed that congruence with planned learning, authenticity, student consultation, and transparency significantly predicted the learning-oriented classroom assessment environment, explaining $48 \%$ of the variance. Congruence with planned learning and student consultation negatively, and diversity positively, predicted the performance-oriented classroom assessment environment, explaining $12 \%$ of the variance. The findings highlight the two core values in classroom assessment tasks: congruence with planned learning and student consultation in mediating the classroom environment.

Percara (2014) in the study, "Supervisors' feedback in ELT practicum as perceived by student-teachers and (their) supervisors" investigated the perceptions of supervisory feedback of student-teachers and university supervisors involved in the teaching practicum, in four EFL teacher education programs at three public universities from the central region of Argentina. In this study, 24 student-teachers and 8 university supervisors from the four EFL teacher education programs were the two groups as the sample of the study conveniently selected based on student teachers' and university supervisors' interests and availability, consisted of two groups. Data were obtained by means of a questionnaire, which included close-ended, and open-ended questions, and semi-structured interviews. In order to analyse the data and allow for the concurrent analysis of both quantitative and qualitative data, a mixed methods approach was employed.

Findings of the study suggested a characterization of supervisory feedback that contributed to deepen the existing knowledge about feedback in the teaching practicum context. Moreover, the results obtained provide relevant information to understand, interpret and anticipate the impact of supervisory feedback on student-teachers and university supervisors in the English Language Teaching (ELT) practicum.

\subsection{The Challenges Encountered by Undergraduate Students during Teaching Practice}

Helminen, (2014) conducted a study to provide an overview of summative assessment of teacher students' practice currently in use in Salford University. Narrative review and synthesis of qualitative and quantitative studies were 
the designs used. Data were collected from the support of an information specialist from scientific databases. Sources used in all of the included studies were also reviewed.

Findings suggest that the assessment process of student teachers' teaching practice lacks consistency. It is open to the subjective bias of the assessor, and the quality of assessment varies greatly. Student teachers' teaching assessment was divided into 3 themes: acts performed before final assessment, the actual final assessment situation and the acts after the final assessment situation. Mentors and students need teachers to provide them with an orientation to the assessment process and the paperwork. Terminology on evaluation forms is sometimes so difficult to grasp that the mentors did not understand what they mean. There is no consensus about written assignments' ability to describe the students' skills. Mentors have timing problems to ensure relevant assessment of student teachers. At the final interview students normally self-assess their performance; the mentor assesses by interview and by written assignments whether the student has achieved the criteria, and the role of the teacher is to support the mentor and the student in appropriate assessment. The variety of students' skills which student teachers impart them with is challenging for the assessment of student teachers' expertise.

Marzieh (2014) conducted her study about, 'Problems and challenges facing undergraduate students' teaching evaluation" in England. The purpose of this qualitative exploratory study was to explore the views of undergraduate students' teaching evaluation problems and drawbacks in Shiraz University. A qualitative exploratory approach was used in this study at Shiraz University 2014. A purposeful sample of 8 instructors and 40 undergraduate students was interviewed and the data on their opinions about the problems of teaching evaluation were collected through semistructured deep interviews. Initially, four open-ended questions, which were related to the teaching evaluation status, problems, were used to stimulate discussions in the interview sessions. Content analysis was employed in order to analyze the transcribed data. The recorded interviews were initially transcribed, read, and reread on a number of occasions to get an overall feeling of what the participants were saying. Each line or incident was described, and then a code, which reflected the essence of the participants' comments were given.

The findings of the study reveal that, the codes were compared for similarity and differences, merged together, and categorized. Finally, five themes emerged: Inappropriate teaching evaluation method, problems of teaching evaluation process, problems related to teaching instructors, unsuitable programming of teacher education, and organizational shortcomings.

Besides focusing on upgrading the current teaching evaluation forms, teacher education trainers should improve their knowledge about a complete and comprehensive teaching evaluation. They should also apply other appropriate and objective teaching evaluation methods and tools, and perform a formative and summative teaching evaluation. Workload adjustment of the educational teachers' trainers needs revision. Therefore, despite using traditional and sometimes limited evaluation methods for assessing student teachers, a comprehensive and appropriate evaluation of student teachers' teaching competencies seems necessary.

A study conducted by Komba and Kiraz in 2013 about "The Effectiveness of Teaching Practice in Improving Student Teachers' Teaching Skills in Tanzania. Morogoro: Sokoine University of Agriculture" was designed to find how Teaching Practice was organized by the teacher training universities and whether the Teaching Practice was effective in improving student teachers' teaching skills. The qualitative research approach was adopted and the study was conducted in Iringa, Morogoro, Dar es Salaam, and Kilimanjaro regions of Tanzania Mainland. A total of 191 student teachers were involved in the study. The findings indicated that the duration spent for the Teaching Practice was inadequate for student teachers to acquire the skills required for effective teaching. Furthermore, the supervision of student teachers during the Teaching Practice was overall, ineffective as the supervisors were not flexible enough to guide, advice, and discuss with student teachers on the strengths and weaknesses revealed during the teaching. Regarding the effectiveness of the Teaching Practice, $76 \%$ of the respondents indicated that Teaching Practice was ineffective in improving their teaching skills. Since the majority of respondents indicated that they did not benefit much from the Teaching Practice, there is need for the responsible authorities to review the procedures for carrying out Teaching Practice in order to improve the quality of teachers.

\subsection{Measures to be undertaken to Improve Teaching Practice Supervision}

Vumilia \& Semali (2016) carried out their study to determine whether the processes of mentoring and socialization that take place during teaching practice (TP) in Tanzania can improve the quality of teacher education. Teacher trainees were asked in a survey to rate their experiences with mentors and state whether pre-service mentoring programs could improve quality education in school classrooms and in teacher preparation colleges.

The findings indicate that mentoring practices benefitted all individuals involved in TP. Teacher trainees benefitted from mentors' models of lesson planning and collaborative teaching, which additionally provided social support. Mentoring strengthened teacher trainees' confidence, self-control, lesson preparation, and classroom presentations. The study also revealed several challenges that students, teachers, and their mentors experience during TP.

The authors of the study have pointed out the benefits of the program but yet in spite of doing so, have failed to find out what perceptions are held by students towards teaching practice assessment processes. The current study strongly involved in determining these perceptions to achieve the quest. However, the study has shown the sample size and used survey in its investigation, the study is said to be practical to the current study which involved survey design particularly mixed approach under convergent design 


\subsection{Summary of Literature Review and Knowledge Gap}

In this chapter, the review of related theories included two theories: Social constructivist Theory of Learning and Computational Theory of Perception and both portray the perception of undergraduate students towards assessment.

The review of the empirical studies, devote itself to the studies that were conducted with the similar concern to that of this study, only differing in different angles. However, almost all literatures did not merge with the current study as far as the core theme is concerned. For instance, studies carried out by Chimhenga (2017) focused on The Student Teachers' Perceptions on Teaching Practice Supervision. The study conducted to determine how supervision took place during teaching practice, but yet it did not identify the perceptions of students towards the teaching practice assessment processes. Namamba and Rao (2017) about Preparation and Professional Development of Teacher Educators in Tanzania but did not reach at the quest of this study about the perceptions of students towards assessment process. Planella (2013) investigated about "Students' perception of peer assessment" University of Girona. Cheng (2015) conducted a study to explore 'The relationship between students' perceptions of assessment tasks and classroom assessment environment, within the university context of teaching English as a foreign language (EFL) in China.

Of all the reviewed literatures, most of them have boldly focused on the perceptions raised by practicing teachers towards the feedback provided by the lecturers, do not answer the research questions of the current study because the previous studies have not addressed on the perceptions of undergraduate students on the university teaching practice assessment process. Since none of the reviewed studies pay attention on the perceptions of undergraduate students towards university teaching practice assessment process, this is a knowledge gap that this study was filled by investigating the perceptions of undergraduate students on the university teaching practice assessment process in Kilimanjaro region, Tanzania.

\section{Research Designs and Methodologies}

The study adopted a mixed approach under Convergent Parallel design (Concurrent triangulation). The convergent parallel design involves a simultaneously collection of both quantitative and qualitative data for the purpose of obtaining a more understanding about the research problem Creswell (2012). The data for this study came from a total of 185 respondents. The students were selected through probability sampling procedures that are simple random sampling and stratified sampling procedures based on gender. Then simple random sampling procedures were used to select 162 third year undergraduate students. Lecturers and TP coordinators were selected through non-probability a sampling procedure that is purposive sampling where by 20 lecturers and 3 TP coordinators drawn from two universities.

Two instruments questionnaire and interview-guide were used to collect data. Questionnaire was applied to undergraduate students while the interview-guide applied to lecturers and TP coordinators. Questions of the questionnaire were in five sections which included both categories: open-ended and closed-ended questions and Likert scale as well.

In-depth Interview Guide was used to lecturers and TP coordinators. For lecturers, consisted of seven sections, A to G. The interview guides for Teaching Practice (TP) coordinators consisted of five sections: A to E; with closed ended questions. The reliability of the instruments was determined by using Cronbach Alpha where as it was determined that the estimated reliability for students was 0.633 which is above 0.5 coefficient, this show that the instruments were considered reliable. In qualitative paradigm, peer briefing and member checking were used to determine reliability of items from interview guide.

Data for this study were computerized and manage under software for easy analysis. Quantitative data collected were sorted and then analyzed by using descriptive statistics (means, frequency and percentages) where computer software that is Statistical Package for Social Sciences (SPSS -version 21) was used. Summarization was done, and their presentation was done in tables. Qualitative data from interview were analyzed through narration and direct quotations. Finally, the hypotheses were tested by using independent $t$ test and Analysis of Variance (ANOVA) to determine the significance different between undergraduate students' gender and age and their perceptions towards university teaching practice assessment process in Kilimanjaro Region. The significance was considered and tested at 0.05 , level of significance.

\section{Results and Discussion}

7.1. The Perceptions of Undergraduate Students towards Feedback Provided by Lecturers after Teaching Practice Assessment

The first research question was concerned to find out how the perceived the feedback of assessments offered by their lecturers. The results that came from questionnaire and interview were presented as following:

Table 1summarizes the findings on the perceptions of undergraduate students towards teaching practice. SA = Strongly Agree, $\mathrm{A}=$ Agree, $\mathrm{U}=$ Undecided and SD = Strongly Disagree. 


\begin{tabular}{|c|c|c|c|c|c|c|}
\hline Variable & \multicolumn{5}{|c|}{ Respondents (\%) } \\
\hline & $\begin{array}{c}\text { Strong } \\
\text { Disagree }\end{array}$ & Disagree & Undecided & Agree & $\begin{array}{c}\text { Strong } \\
\text { Agree }\end{array}$ & $\begin{array}{c}\text { Mean } \\
\text { score }\end{array}$ \\
\hline $\begin{array}{c}\text { Lecturers provided assessment feedback } \\
\text { on time }\end{array}$ & $1(0.6)$ & $4(2.5)$ & $6(3.7)$ & $84(51.9)$ & $67(41.4)$ & 4.31 \\
\hline $\begin{array}{c}\text { Lecturers are fair in their teaching practice } \\
\text { assessment }\end{array}$ & $1(0.6)$ & $17(10.5)$ & $42(25.9)$ & $79(48.8)$ & $23(14.2)$ & 3.65 \\
\hline $\begin{array}{c}\text { Feedback is provided by the lecturer } \\
\text { regularly at the end of the lesson }\end{array}$ & $1(0.6)$ & $16(9.9)$ & $6(3.7)$ & $88(54.3)$ & $51(31.5)$ & 4.06 \\
\hline $\begin{array}{c}\text { I improve my performance in teaching } \\
\text { practice after supervision }\end{array}$ & $2(1.2)$ & $2(1.2)$ & $9(5.6)$ & $76(46.9)$ & $73(45.1)$ & 4.33 \\
\hline $\begin{array}{c}\text { Assessment leads to the improved change } \\
\text { of my teaching and learning strategies }\end{array}$ & $1(0.6)$ & $2(1.2)$ & $4(2.5)$ & $81(50.0)$ & $74(45.7)$ & 4.39 \\
\hline $\begin{array}{c}\text { Lecturer provides me with opportunity to } \\
\text { reflect on my teaching }\end{array}$ & $1(0.6)$ & $13(8.0)$ & $46(28.4)$ & $63(38.9)$ & $39(24.1)$ & 3.78 \\
\hline $\begin{array}{c}\text { Lecturers feedback provided positive } \\
\text { change in my performance }\end{array}$ & $3(1.9)$ & $2(1.2)$ & $7(4.3)$ & $62(38.3)$ & $88(54.3)$ & 4.42 \\
\hline $\begin{array}{c}\text { Teaching practice is useful in the training } \\
\text { of Teachers }\end{array}$ & $1(0.6)$ & - & $3(1.9)$ & $59(36.4)$ & $99(61.1)$ & 4.57 \\
\hline $\begin{array}{c}\text { Lecturers Feedback is not necessary at the } \\
\text { end of the lesson }\end{array}$ & $48(29.6)$ & $60(37.0)$ & $31(19.1)$ & $15(9.3)$ & $8(4.9)$ & 2.23 \\
\hline $\begin{array}{c}\text { Uniformity in teaching practice } \\
\text { assessment is enhanced }\end{array}$ & $4(2.5)$ & $7(4.3)$ & $29(17.9)$ & $98(60.5)$ & $24(14.8)$ & 3.81 \\
\hline $\begin{array}{c}\text { Feedback provided by lecturers is } \\
\text { ineffective in building students self esteem }\end{array}$ & $38(23.5)$ & $62(38.3)$ & $24(14.8)$ & $27(16.7)$ & $11(6.8)$ & 2.45 \\
\hline $\begin{array}{c}\text { Teaching practice assessment promotes } \\
\text { achievements of academic objectives }\end{array}$ & - & - & $2(1.2)$ & $80(49.4)$ & $80(49.4)$ & 4.48 \\
\hline $\begin{array}{c}\text { My lecturer provides dishonest feedback } \\
\text { after teaching }\end{array}$ & $49(30.2)$ & $70(43.2)$ & $24(14.8)$ & $13(8.0)$ & $6(3.7)$ & 2.12 \\
\hline $\begin{array}{c}\text { Teaching practice assessment prepares me } \\
\text { to become a competent professional }\end{array}$ & - & - & $3(1.9)$ & $53(32.7)$ & $106(65.4)$ & 4.64 \\
\hline $\begin{array}{c}\text { Overall } \\
\text { Tean }\end{array}$ & Mcore & & & & 3.81 \\
\hline
\end{tabular}

Table 1: Undergraduate Students' Perceptions towards Feedback Provided by Lecturers after Teaching Practice Assessment (N=162)

As it may be seen in the table the responses that came from undergraduate students reveal that; 151 (96.3\%) of undergraduate students responded that lecturers provided assessment feedback on time; $139(85.8 \%)$ of undergraduate students responded that feedback is provided by lecturers regularly at the end of the assessments; 160 (98.8\%) of undergraduate students responded that teaching practice assessments promoted achievements of academic objectives;159 (98.1\%) of undergraduate students agreed that Teaching practice assessment prepared them to become competent professionals; $119(73.4 \%)$ responded that lecturers provide dishonest feedback after assessment; 108 $(66.6 \%)$ disagreed that lecturers feedback was not necessary at the end of the assessment;100 (61.8\%) disagreed that feedback provided by lecturers is ineffective in building students' self-esteem.

For the great depth of students' response, they were also asked to generally rate their perceptions towards the assessments program. Their response revealed that the assessment was fair. This is observed from the following table of their response.

\begin{tabular}{|c|c|c|}
\hline Variable & \multicolumn{2}{|c|}{ Frequency (\%) } \\
\hline & Positively (\%) & Negatively (\%) \\
\hline $\begin{array}{c}\text { Feedback provided by lecturers after teaching practice } \\
\text { performance perceive to students teachers }\end{array}$ & $120(81.6)$ & $26(17.7)$ \\
\hline
\end{tabular}

Table 2: Students' Perceptions on the Feedback Provided by Lecturers after

Teaching Practice Performance (N=146) Source: Field Data 2018

As portrayed in the table: 120 students (81.6\%) commented that the assessment was perceived positively while only 26 students $(17.7 \%)$ responded that assessment program was perceived negatively. As the scenario is concerned; assessment program was found to be fair as majority of students perceived it positively. This has a great implication on the students' better performance during the teaching practices and in their professional development at large. Further, the findings agree with that of Diab (1999) at King Faisal University in his study on student teachers' attitudes towards teaching practice and supervisor as critical in determining the extent to which the trainees get involved in the teaching 
process. The study found that student teachers' attitudes towards the following were positive: supervisor effectiveness, and the extent of follow up by supervisor.

Through the interview TP coordinators supported the findings by answering the question about students' perception as all coordinators responded that the feedback on assessment was perceived positively by undergraduate students. To support the findings, they stated that assessment feedback laid a foundation for their career development whereas the coordinator from university two supported the findings by saying:

Undergraduate students perceive feedback positively, this is because they know that feedback help them to improve, change from weaknesses to strengths, help them to correct mistakes. But very few perceive negatively due to various reasons: others do not like feedback provided especially weaknesses, others due to how lecturers provide feedback (harshness) (18th July, 2018)

These findings are consistent with those observed by Albasheer, Khasawneh, Abu, and Hailat (2008) in which student teachers believed that university supervisors' feedback helped them to plan comprehensive daily lesson plans, combine a theoretical perspective with practice in the instructional process, provide appropriate instructions to improve performance and progress individually and collectively.

Another coordinator stated that:

Feedback helps undergraduate students to perform better, especially those who are visited first by monitors than those who are not visited by monitors (18th July, 2018)

When asked about the perception of undergraduate students towards the assessment feedback; university lecturers responded that the there was positive perceptions demonstrated by students. It was said that students were free to interact with their lectures and were able to ask questions and lay down their opinions. These were said to be important in making assessments accurate. During the interview one lecture said that:

Undergraduate students perceive feedback positively. Because feedback help them to improve for their future performance on teaching. Since they have the time to ask questions to me, and monitors, reflect himself/ herself on his/ her teaching. They share their own opinions on the given feedback something which show the acknowledgement of the feedback given (18 th July, 2018)

Another lecturer added:

Feedback provided by lecturers, help them to use similar approach to give feedback to their colleagues during peer observation. Moreover, feedbacks motivate students to study hard and hence become complete in teaching process (18 ${ }^{\text {th }}$ July, 2018)

Similarly, one lecturer added that:

Undergraduate students perceive feedback positively. Because feedback help them to improve for their future performance on teaching. Since they have the time to ask questions to me, and monitors, reflect himself/ herself on his/ her teaching. They share their own opinions on the given feedback something which show the acknowledgement of the feedback given (18 th July, 2018)

Another lecturer added:

Feedback provided by lecturers, help them to use similar approach to give feedback to their colleagues during peer observation. Moreover, feedbacks motivate students to study hard and hence become complete in teaching process (18th July, 2018)

Relying on the findings that came from undergraduate students, majority of the respondents (Lecturers, students and coordinators) responded with positive comments. From their comments it was said that assessment feedback is perceived positively among the undergraduate students. This is because assessment helps in building confidence in teaching/ learning activities, help in mastering subject matter and teaching methodologies, feedback is regularly provided after assessments; it is provided on time and therefore helps undergraduate students to improve their weaknesses as a way forward to develop their career. This indicates that, the respondents perceived that feedback during teaching practice is very important because a person cannot become a good teacher without it.

These findings are consistent with those observed by Ng'eno, Wambungu \& Barmao, (2013) as they hold that the student teachers' perceptions towards teaching practice is said to be favorable. Being favourable the perceptions are said to be helpful in enhancing teaching practice assessment. So according to the findings it shows that undergraduate teachers have positive perceptions towards teaching feedbacks provided by their lecturers since it helps them to improve, and these findings is in line with those of Mahende and Mabula (2013), which shows that majority of student teachers responded that teaching practice is for improvement and not for grading.

\subsection{Challenges Encountered during teaching Practices Assessments in Kilimanjaro Region}

On the third research question, the researcher sought to challenges encountered by students, lecturers and TP coordinators to hinder the effective assessment of the teaching practices. Obtained results were presented in table below and qualitatively. 


\begin{tabular}{|c|c|c|}
\hline Variable & Frequency & Percent \\
\hline Accommodation problems & 24 & 5.3 \\
\hline Few buildings and learning materials & 142 & 31.6 \\
\hline Harshness from some lecturers & 18 & 4.0 \\
\hline Inadequate of teacher's especial science teachers & 19 & 4.2 \\
\hline Interference between monitor and supervisors in assessing & 9 & 2.0 \\
\hline Lack of cooperation between Teachers and Students Teachers & 52 & 11.6 \\
\hline Late coming of lecturers in assessing & 15 & 3.3 \\
\hline Limited region for BTP & 15 & 3.3 \\
\hline Limited Teaching practice duration & 34 & 7.6 \\
\hline Poor environmental condition (remote areas) & 36 & 8.0 \\
\hline Lack of monitors to some schools & 15 & 3.3 \\
\hline Language barriers & 15 & 3.3 \\
\hline Unfair assessment done by some lecturers & 3 & 0.7 \\
\hline Poor cooperation from students & 18 & 4.0 \\
\hline Shortage of fund & 34 & 7.6 \\
\hline
\end{tabular}

Table 3: Undergraduate Students' Responses about the Challenges Encountered during Teaching Practice Assessment ( $\mathrm{N}=162$ )

Table 3 portrays that, majority of students $142(31.6 \%)$ responded that there were serious shortage of buildings and learning materials like text books, laboratories and libraries, which make the teaching practice difficult for them; $34(7.6 \%)$ responded that there was shortage of funds. Undergraduate students were posted to nearest TP centers which would not cost much money for transportation. Choosing centers for TP on the basis of distance might distract the purpose of assessment; (3.3\%) responded that regions for TP were limited as the selection was based on the opportunity cost. The furthest institutions were not considered so as to avoid financial cost; 36 (8.0\%) commented that poor environmental condition was among the challenges as other schools were situated in remoteness areas in which meeting important social services was difficult; 34 (7.6\%) commented that there was limited Teaching practice duration as they had to attend their TP for only 4 weeks which would not enhance effective acquisition of experience for student teachers required for effective teaching; 24 (5.3\%) of undergraduate students raised accommodation problems as one of the challenges during teaching practice.

From the result it shows that during teaching practice undergraduate students are facing problem of accommodation which build negative perceptions towards teaching practice. Due to lack of funds universities would finance their undergraduate students satisfactorily; 15 (3.3\%) responded that late coming of lecturers in assessment was a barrier for which they could not recognize their weaknesses and strengths and make timely changes and 19 (4.2\%) responded that the inadequacy of science teachers made the TP difficult as they were assigned with huge responsibilities when posted to schools for TP and 15(3.3\%) of undergraduate students responded that there was lack of monitors in some schools who would go for first assessments so as to prepare them for the final assessment. It might have forced them to remain unchanged even when they were making mistakes in their teaching practice until assessors came.

This could imply that undergraduate students have negative perceptions toward teaching and learning environment in which it creates unfavorable environment towards teaching practice. Caccioppo (1994) noted that in behaviorism theory, attitude towards stimuli was posited to become more favorable or unfavorable if they were associated with pleasant or unpleasant context or led to positive or negative outcomes.

When interviewed, lecturers raised various challenges that were found to be barriers towards assessments. Lecturers supported the findings by answering the question that required them to supply the challenges that were found to be barriers towards assessments. From their response challenges like lack of funds, short TP duration, students teaching methods and approaches were found to be the challenges that hindered the effective implementation of the program. In their responses it was found out that: the accommodation of students while in their field of practices was a problem and the time spends for a practice was short and it becomes a problem in determining the students' achievement. The lecturers responded as follows:

One of lecturers from university one reported:

There is shortage of budget to this undertaking teaching practice to both lecturers and students, especially students. As the result they do not do well in their practice, they become frustrated and hence fail to score better (17th July, 2018)

As it was reported by students, this challenge was found to be facing lecturers. This proves that the challenge is serious and therefore should be looked at it for improvement.

The other response that came from another lecturer was based on the teaching methods. This lecturer said,

Students using similar methods in teaching, example; questions and answers, group discussion and lecture as if are the only methods of teaching (17th July, 2018)

One would have said that students were passive, and this is due is might perhaps be resulted by ineffectiveness in their preparation for their assessments.

Also, another lecturer argued that:

Among the challenge that face during teaching practice is limited teaching practice duration. The practice of teaching is done in too short time example only one month not enough for student to 
understand better the practice. Moreover, preparation for teaching practice to students is not enough.

They are prepared only when are going to the field (17th July, 2018)

Teaching practice coordinators also were asked on the challenges facing them on their responsibilities during the whole process of teaching practice. Coordinators responded that there are many challenges that hinder the smooth development of the process. The challenges stated were: Some schools return back undergraduate students because of misbehavior, irresponsibility in schools, so coordinators have to find other schools for them. Limited regions for TP. Students complain to coordinators on the situation. Overloaded among TP coordinators especially during TP preparation. Interference between supervision time and school timetable; like weekly test and monthly test.

One coordinator stated:

Some students do not attend TP orientation hence later fail to follow instructions example; submission

of portfolio on time, submission of letter, fail to perform effective schools, misbehave, prepare weak scheme of work and lesson plan

Other challenges were said to be the shortage of teaching/ learning materials in schools, some undergraduate students do not attend TP orientation hence do not do better in schools. This is because they do not know the changes explained in the orientation, some students misbehave in schools; example improper dressing, does not participate in some extracurricular activities in schools' example: sports and games. Number of visits for assessment is not enough (only once) does not help to show clearly if the trainees are competent or not, have improved or not. Lecturers assess too many contents, which lead them to supervise partially. The findings are similar to that of Marzieh (2014) who found that, student teachers' effectiveness is hindered by some challenges like: inappropriate teaching evaluation method, problems of teaching evaluation process, problems related to teaching instructors, unsuitable programming of teacher education. All these challenges lead the undergraduates to have negative perceptions towards teaching practice and hold back good progress of teaching practice assessment process. So, these must be solved so as to improve the process.

\subsection{Measures to Improve Teaching Practices Supervision of Undergraduate Students in Kilimanjaro Region}

Following the discovered challenges, in the third research question, the researcher sought to know the strategies that would be involved to improve assessment programme. The results were presented below.

\begin{tabular}{|c|c|c|}
\hline Variable & Frequency & Percent \\
\hline $\begin{array}{c}\text { Ensuring the availability of enough building and learning } \\
\text { materials }\end{array}$ & 104 & 25.7 \\
\hline $\begin{array}{c}\text { To specify time for which monitors and supervisors to be } \\
\text { supposed in school }\end{array}$ & 14 & 3.5 \\
\hline $\begin{array}{c}\text { Control discipline of the students } \\
\text { Good cooperation between staff and students' teachers }\end{array}$ & 10 & 2.5 \\
\hline Improvement of infrastructure systems & 15 & 10.6 \\
\hline Improvement of teaching methodology and school time table & 5 & 3.7 \\
\hline Improvement of environmental condition & 19 & 1.2 \\
\hline Provision of accommodation & 41 & 10.7 \\
\hline Lecturers should be fair and assess all students & 28 & 6.9 \\
\hline Lecturers should come on time & 3 & 0.7 \\
\hline Increasing time for BTP & 21 & 5.2 \\
\hline Increase funds to students & 72 & 17.8 \\
\hline The use of English language in schools & 13 & 3.2 \\
\hline Lecturers should assess their subjects & 8 & 2.0 \\
\hline Reduction of harshness to some Lecturers & 9 & 2.2 \\
\hline
\end{tabular}

Table 4: Undergraduate Students' Responses on Measures to Mitigate the Challenges

Faced during Teaching Practice Assessment ( $\mathrm{N}=162)$

Presented in table 4.12 were the proposed measures from the undergraduate students whereby; 72 students (17.8\%) suggested for increasing funds to students. This fraction suggested one of the solutions to a financial problem which they raised as a challenge. Another solution suggested was the provision of accommodation to students when they are in the TP centers, by41 students (10.1\%). They raised this solution as financial support alone would not help but ensuring the required needs. Other 43 students (10.6\%) called for cooperation between staff and undergraduate students. This is an ideal solution that is likely to make working environment suitable to student-teachers. These students require mentorship from the practicing teachers that would minimize some of the weaknesses. Ensuring availability of buildings and $\mathrm{T} / \mathrm{L}$ resources was among the suggestions that came from 104 students $(25.7 \%)$. They called upon this suggestion as some schools are lacking some facilities, with this scarcity TP became a burden to them hence performed poorly when assessed. Improvement of TP centers was suggested to be taken into consideration, 19 students (4.7\%) proposed that they ought to be posted to the centers where their practices would be done precisely. Other measures were; increasing time for TP as was suggested by 21 (5.2\%) of the undergraduate students; instilling fairness of assessment among lectures by 28 $(6.9 \%)$ of the students and improving undergraduate students' discipline that was suggested by10 (2.5\%). These students believed that when a student observes discipline; is likely to do better in his/ her studies. 
Unlike undergraduate students who answered questions of the questionnaire, lecturers and coordinators were interviewed. Interviewing them was purposely for obtaining concrete solutions. To support for the measures to be involved in improving assessment, extension of TP duration, adopting multiple teaching methods, considering the distance on the choice of schools for TP and training supervisors were the suggestions provided by lecturers. It was said from one lecturer that,

There should be addition of teaching practice duration for big results if we want good education, good

teachers and big results must be invested in teachers training and excellent practice (five weeks are not

enough, there should be at least ten weeks) (17th July, 2018)

As proposed by some of the students; this is much desired, and it will enhance effective assessments. Will sufficient time for teaching practices students will have enough time to make improvements when necessary.

Another lecturer from university two proposed for the teaching methods as he said that:

Undergraduates must be encouraged to use other teaching methods than questions and answers, and

group discussion. Methods like: social barometer, odd one out, host seat, exit tickets (17th July, 2018)

This is real on the basis that when the students employ the use of these methods makes the teaching more practical and enhances effective learning.

Another lecturer called upon the engagement of monitors in the practice as one of them said:

Monitors should start at the beginning of the teaching practice in order to avoid interference between

monitors and lecturers. Also, all students should be visited by monitors not only some students (17th

July, 2018)

Further findings were provided by lecturers that:

Geographical location of the institutions where students practice should be mapped and improved to avoid cost and convenience, head of schools and teachers of the institutions concerned should look on students, time to time for the development of students. Also, must strictly provide report to the TP coordinators about student-teachers performance and behavior and alternative ways must be found to make sure that all students attend TP orientation. This is because there are some changes which occur in each orientation.

Another lecturer from university one added that:

Supervisors who are not teachers should be given special trainings each year in order to improve their knowledge and skills in teaching. This will help to avoid imagination results of students. Suggested that if possible, only those lecturers with education background (teachers) should be involved in TP supervision not otherwise (17th July, 2018)

When TP coordinators were interviewed about the measures to be incorporated, they responded that the attitude towards the practice should be meant to equip trainees with skills required, together with ensuring a reliable number of assessors. They therefore suggested that teaching practices should be done effectively, increment of budgets and the number of supervisors.

One coordinator supported the findings by saying:

Schools should take teaching practice as the process or the way of preparing the future teachers and not to solve their problems (not for their benefit) or an event. Moreover, should be able to receive and help trainees to improve their teaching (17th July, 2018)

Other coordinator from university two argued that:

There should be addition of manpower during teaching practice preparation and expansion of budget that should be provided to students from their parents, loan board or relatives. Moreover, Schools should take teaching practice as the process or the way of preparing the future teachers and not for their benefit or an event (17th July, 2018)

Based on these findings, undergraduate students, lecturers and coordinators offer the best ground for effective and reliable assessments of teaching practices among undergraduate students. Improvements in different areas like the relationship between practicing teachers and in-service teachers, improvement of accommodation, extension of budget and time for TP, equipping students with reliable teaching methods and techniques together with the improvement centers for Teaching Practice are likely to take assessment program to the desired purpose and make the students to have positive perceptions towards it. The findings are similar to that of Vumilia and semali (2016) who state that: mentoring should devote in strengthening teacher trainees' confidence, self-control, lesson preparation, and classroom presentations.

\section{Conclusion and Recommendations}

\subsection{Conclusions of the Study}

The study concluded that there are positive perceptions among undergraduate students on the university assessment process during the teaching field practice assessment in Kilimanjaro region Tanzania. Undergraduate students perceive teaching practice as an important component in their training because it exposes them to the actual teaching and learning environment in which they can contextualize their theoretical knowledge gained during training. Teaching practice assessment helps in building confidence in teaching/learning activities, help in mastering subject matter and teaching methodologies, helps undergraduate students to improve their weaknesses as a way forward to develop their career.

On the other hand, it was also concluded that the implementation of the assessment programme among Kilimanjaro universities was encountered by several challenges. The challenges faced undergraduate students, lecturers and TP coordinators. These challenges were accommodation problem to undergraduate students, shortage of teaching 
/ learning materials in schools, inadequate funds and untimely schedule for Teaching practices. Number of visits for assessment is not enough (only once) does not help to show clearly if the trainees are competent or not, have improved or not. Lecturers assess too many contents, which lead them to supervise partially. Furthermore, it was concluded that a number of strategies can be carried out against the challenges in order to solve the prevailing challenges. These measures were proposed to be: the provision of accommodation, increasing time for TP, increase funds to students, improvement of environmental condition, ensuring the availability of enough building and learning materials were termed as effective strategies.

Finally, two hypotheses were tested to find out if there were the significance mean scores different between undergraduate students' gender and age with their perceptions towards teaching practice assessment process. The conclusion was drawn that there were no mean score differences between undergraduate students' gender and age with their perceptions towards teaching practice assessment process.

\subsection{Recommendations of the Study}

\subsubsection{Recommendations for Action}

- The study recommended that, the government through Ministry of Education Science and Technology (MoEST) should formulate a good policy that lay a uniform period of teaching practices among the teacher education institutions, support teaching practice by providing enough funds that would be used for accommodation and food.

- The study recommended that, University principals should allocate undergraduate students to the schools having conducive environment for teaching, enough teaching/ learning materials and the university lecturers should be well trained to have enough knowledge and skills on how to conduct teaching practice assessment.

- The TP coordinators should promote ethical dimension of undergraduate students with respect to professional code of conduct and organize seminars for all supervisors before visiting the student teachers in schools.

- In the schools where student teachers are posted for their Teaching Practice, heads of schools should be encouraged to do a continuous evaluation of student teachers throughout the Teaching Practice. Finally, the government should invest more in the training of teachers for the betterment of the nation.

\subsubsection{Recommendations for Further Studies}

- Further studies should be conducted on; the due effort of Tanzania Commission for Universities towards professional teacher development.

- A study should be conducted to statistically test the significance of the impact of the duration of teacher training in relation to teachers' competencies and work performance.

- A comparative study should be done on perception of student teachers towards teaching practice in different universities in Tanzania.

\section{References}

i. Aiken, L. R. (2000). Psychological Testing and Assessment (10 thed.). Boston: Allyn and Bacon.

ii. Albasheer, A., Khasawneh, S., Abu, N. A., and Hailat, S. (2008). Perceptions of student teachers towards the effectiveness of Cooperating Teachers, School Principals and University Supervisors Participating in the Teacher Education program in Jordan.

iii. International Journal of Lifelong Education, 27(6):693-705.

iv. Al-magableh, A.M. F 2010.An Evaluation of English Practicum at Yormuk University from Cooperative Teachers and Student- Teachers Perspectives. International Journal of Language Studies (IJLS), vol.4 (4),263-300.

v. Alnaji, H. (2000). An Evaluation of Pre-service Practicum at Mu'tah University from GraduatesPerspectives. Mu'tah for Studies and Research,15 (3),179-205.

vi. Alsaid, M. (2001). Efficiency of a Suggested Program for Developing Art Education Student- Teachers' Critical Thinking and its Influence on the Outcomes of the Teaching Process. Studies in Curricula and Instruction, 71, 83-221

vii. Bachore, S. (2016). Students' perceptions about Evaluation and Assessment in Higher

viii. Education: a Review1: Leuven, Taylor \& Francis Ltd.

ix. Bakhshi, H., Hassanshahi, G., \&Bakhialiabad, M.H. (2015).Students' Perceptions of the $\quad$ Academic $\quad$ Learning Environment in Seven Medical Sciences Courses Based on Dreem. US: National Library of Medicine

x. Bhargara A. \&Pathy M. (2011).Perception of Students Teachers about Teaching Competencies. American International Journal of Contemporary Research vol. 1(1)77-81

xi. Bogman, R. \& Biklen, S. (1992). Qualitative Research for Education: An Introduction to Theory and Method. Boston: Allyn and Bacon.

xii. Caccioppo J.T. (1994). Attitude Change. Psychology. Uchicago.edu/ people/ Faculty.

xiii. Retrieved on $13^{\text {th }}$ October, 2013. 5.15pm.

xiv. Cheng, L (2015). Chinese University Students' Perceptions of Assessment tasks and Classroom Assessment Environment. Kingston: Queen's University.

xv. Cherry, M. (2013). Merrill. Problems Experienced in Evaluating Success and Performance in Distance Education: A Case Study. Turkish Online Journal of Distance Education, 18(1).

xvi. Chimhenga, S (2017). The Student Teachers' Perceptions on Teaching Practice Supervision: 
xvii. Is It A Process Of Grading Or Improvement Of Teaching Skills? Harare; Zimbabwe

xviii. Open University.

xix. Chireshe, R. \&Chireshe, E (2010).Student Teachers Perception of Teaching Practice Assessment. South African Journal of Mathematics Education Vol. 3(1) 119-136.

xx. Creswell J.W. (2012). Educational Research: Planning, Conducting and Evaluating Quantitativeand Qualitatitave Research (4th Ed). Boston: Pearson.

xxi. Démuth, A. (2013). Theories of Perception. European Union: Trnava.

xxii. Diab,T. 1999. Student- Teachers Attitudes towards Practicum at Jordan University: An

xxiii. Evaluative Study. Divvasat, Education Sciences, 26(1), 142-164

xxiv. Donald, D. \&Hoffman, D.D. (2011). The Interface Theory of Perception: Natural Selection DrivesTrue

Perception to Swift Extinction.

xxv. Goh, P. S. \& Matthews, B. (2011). Listening to the concerns of student teachers in Malaysia duringteaching practice. Australian Journal of Teacher Education, 39 (3), 226-246.

xxvi. Jahin\& Alexander 2006.Saudi EFL Student Teachers' Beliefs about Language Learning: The Impact of a

Preservice Teacher Education Programme. Studies in Curriculum and Instruction, 110, 1-30.

xxvii. Helminen, K. (2014). Summative Assessment of Clinical Practice of Student Nurses: A

xxviii. Review of the Literature. United Kingdom: University of Salford.

xxix. Komba, C.S.\&Kiraz, E.S. (2013).The Effectiveness of Teaching Practice in Improving

xxx. Kombo, D.K. \& Tromp, L.A. (2006).Proposal and Thesis Writing: an introduction. Nairobi: Paulines Publishers.

xxxi. Lukanga A.L. (2013). The Experience of Pre-ServiceTeacher Preparation for Quality Education: www.tenmet.org/ Droop/ QES\%202013/ Lukanga.Pdf.

xxxii. Mahende, A.G \&Mabula, N. (2013). Is Teaching Practice for grading or Improvement?

xxxiii. Examining Student Teachers' Perception and Experience at the University of Dar es

xxxiv. salaam, Tanzania. Dar es Salaam: Dar es Salaam University

xxxv. Malik, S. \&Ajmal, F. (2010).Levels, causes and Coping Strategies of Stress During $\quad$ Teaching $\quad$ practice. Journal ofLaw and Psychology, 1 (1), 2078-1083.

xxxvi. $\quad$ Marzieh, R. (2014). Student Perceptions of Peer Assessment: an Interdisciplinary study:

xxxvii. London, Routledge Informa Ltd.

xxxviii. Matto, G.\&Madila, S. (2014).University Students Perceptions on the Effectiveness of open-

Solving Questions in online Exams in Tanzania: Moshi, MUCOBS.

xxxix. MOEVT. (2011). Mwongozo wa Mafunzo ya Ualimu kwa Vitendo, Rasimu: Dar es salaam.

xl. Mpapalika, M.K (2013). Tanzania Science Teachers' Practices and Challenges in Continuous Assessment. Johannesburg: University of Witwatersrand.

xli. Mussawy, A.J. (2009). Assessment Practices: Student's and Teachers' Perceptions of Classroom Assessment. A Mmhret: University of Massachusetts

xlii. Namamba, A.\&Rao, C. (2017).Preparation and Professional Development of Teacher Educators in Tanzania: Current Practices and Prospects. Changchun City: Notheastnormal University.

xliii. Ng'eno, J., Wambungu, P., \&Barmao, A. (2013).Student Teachers' Perceptions of Teaching Practice Assessment in Egerton University, Kenya. Nairobi: Egerton University

xliv. Ngussa, B.M. \& Kuboja, J.M. (2015).Teaching Practice Self Evaluation: Experiences at the

xlv. University of Arusha- Musoma Centre, Tanzania: Arusha, University of Arusha

xlvi. Olugbenga A, (2013). Policy support and performance of small and medium enterprises in

xlvii. South west Nigeria, Adaramola, Nigeria.

xlviii. Percara, A. (2014). Supervisors' feedback in ELT practicum as perceived by student-

xlix. teachersand (their) supervisors". Buenos Aires; Universidad Nacional de Córdoba.

1. Planella, P.J (2013). Assessment \& Evaluation in Higher Education. Spain: University of

li. Girona

lii. Popham, W.J. (2008). Classroom Assessment: What Teachers Need to Know (5 ${ }^{\text {thed.) }}$

liii. Boston: Pearson/ Allyn and Bacon.

liv. Sax, G., \& Newton, J.W. (1997). Principles of Educational and Psychological Measurement and Evaluation (4 ${ }^{\text {th }}$ ed.). Belmont, Calif.: Wadsworth.

lv. Smith, K., \& Lev-Ari, L. (2005).The place of Practicum in Pre-service Teacher

lvi. Education. Asian Pacific Journal of Teacher Education, 33(3), 289-302.

lvii. TCU (2014).General Guidelines and Minimum Standards for Provision of University

lviii. Education in Tanzania. Dar es Salaam: TCU

lix. Thungu, E. (2010). Teaching Practice: a make or Break Phase for Student Teachers.

lx. South African Journal of Education. Vol 29: 345-358.

lxi. Vumilia, P.\&Semali, L. (2016).Can the Mentoring and Socialization of Pre-Service Teachers Improve Teacher Education? Moshi: Mwenge Catholic University

lxii. Wiliam, D.(1998). Enculturating Learners into Communities of practice: Raising Achievement through Classroom Assessment. London: King's College. 